15 Thompson SC, Jolley D, Marks R. Reduction of solar keratoses by regular sunscreen use. $N$ Engl $f \mathrm{Med}$ 1993;329:1147-51.

16 Mommaas AM, van Praag MCG, Bouwes Bavinck JN, Out-Luiting C, Vermeer BJ, Claas FHJ. Analysis of the protective effect of topical sunscreens on the UVB-radiation-induced suppression of the mixed-lymphocytetion-induced suppression of the mixed-1

17 van Praag MCG, Out-Luiting C, Claas FHJ, Vermeer BJ, Mommaas AM. Effect of topical sunscreens on the UV radiation-induced suppression of the alloactivating capacity in human skin in vivo. $\mathcal{f}$ Invest Dermatol 1991; 97:620-3.

18 Shuttleworth D, Marks R, Griffin PJA, Salaman JR Treatment of cutaneous neoplasia with etretinate in renal transplant recipients. $O \mathcal{F}$ Med 1988;68:717-24.

19 Kelly JW, Sabto J, Gurr FW, Bruce F. Retinoids to prevent skin cancer in organ transplant recipients. Lancet 1991, 338: 1407 .

20 McKerrow KJ, MacKie RM, Lesko MJ, Pearson C. The effect of oral retinoid therapy on the normal human immune system. Br f Dermatol 1988;119:313-20.

\title{
Direct evidence of patent foramen ovale as a route for paradoxical embolism
}

\author{
E Balli, A Alfieri, F Del Citerna
}

Coronary Care Unit, Della Robbia Hospital, Pistoia,

Italy

E Balli

A Alfieri

F Del Citerna

Correspondence to:

Dr E Balli, Unità

Coronarica, Ospedale di Pistoia, Viale Matteotti, 51100 Pistoia, Italia

Accepted for publication 12 June 1995

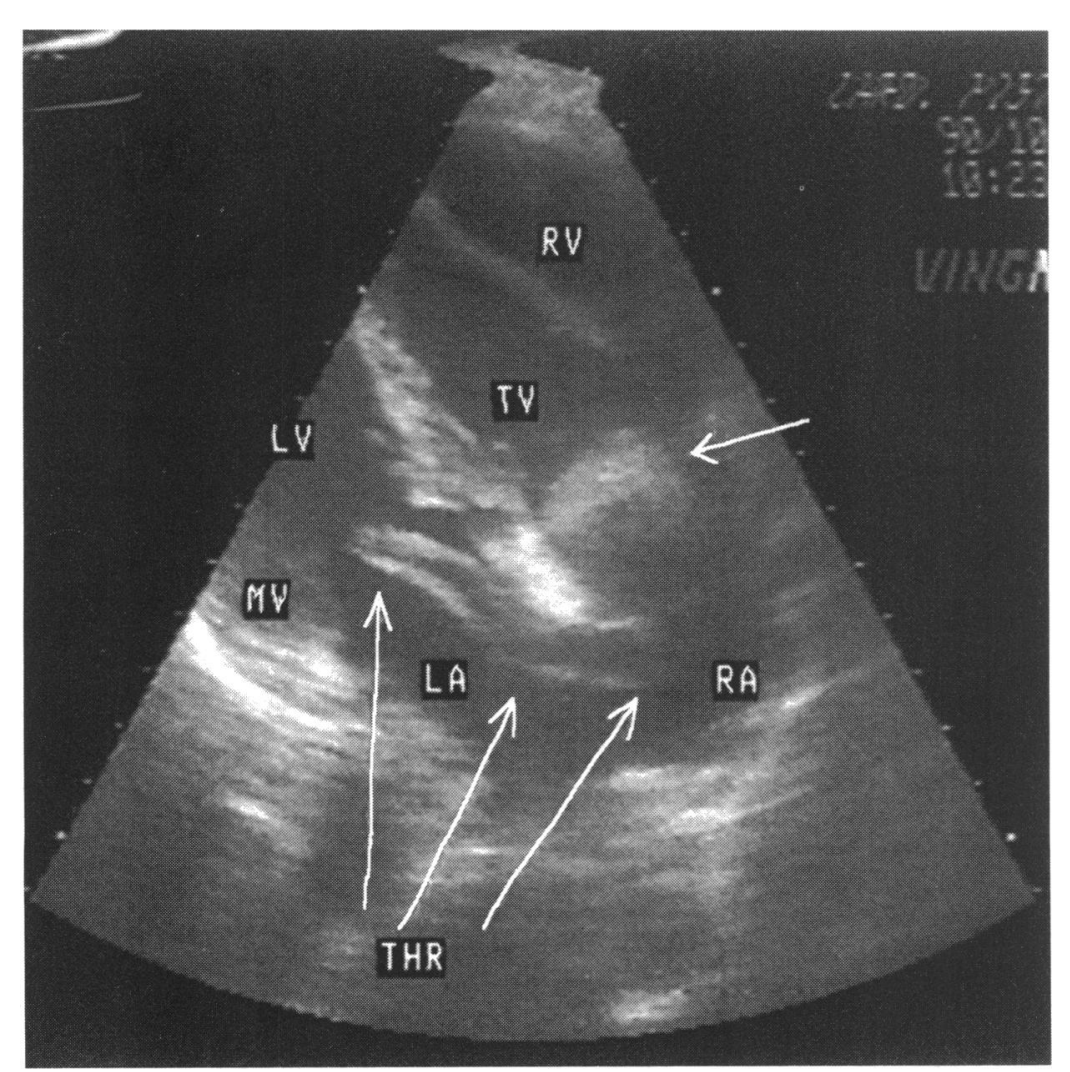

Transthoracic echocardiogram (modified right ventricular inflow tract view, diastolic frame) showing the thrombus (THR, arrows) abutting the tricuspid valve (TV) and crossing the interatrial septum at the level of foramen ovale to impinge on the mitral valve

$(M V) . R V$, right ventricle; $L V$, left ventricle; $R A$, right atrium; $L A$, left atrium.

\begin{abstract}
A 83 year old woman was transferred from the department of surgery because of a syncopal attack with hypotension. Twenty days before she had had a palliative operation for gall bladder adenocarcinoma with hepatic invasion. Some days later she had had an ischaemic stroke in the middle cerebral artery territory, which was confirmed by computed tomography. Carotid ultrasonography showed no stenoses. Despite these clinical events and prolonged immobilisation, she could be treated only with low-dose subcutaneous heparin because of postoperative gastric
\end{abstract}

haemorrhage which required blood transfusions. Transthoracic echocardiography (TTE) showed a thrombus abutting the tricuspid valve and crossing a patent foramen ovale to reach the left atrium and mitral valve (figure). A Doppler estimate of right ventricular systolic pressure was about $75 \mathrm{~mm} \mathrm{Hg}$.

A patent foramen ovale is a risk factor for ischaemic stroke ${ }^{1}$; indirect evidence of its role as a route for paradoxical embolism through a right-to-left shunt stems from case-control studies. ${ }^{23} \mathrm{~A}$ direct role is difficult to demonstrate, ${ }^{4}$ because diagnosis of paradoxical embolism is based upon indirect criteria, ${ }^{5}$ and documentation of a patent foramen ovale itself usually requires transesophageal echocardiography, with intravenous saline contrast when necessary. ${ }^{1}$

This patient had several risk factors for deep vein thrombosis, such as old age, adenocarcinoma, recent surgery, and prolonged immobilisation: but she also had contraindications to antithrombotic therapy. ${ }^{6}$ The shape of the thrombus indicated a venous genesis. Pulmonary hypertension probably forced open the foramen ovale, ${ }^{5}$ leading to an interatrial shunt. The thrombus across the interatrial septum may explain the ischaemic stroke and confirm the role of patent foramen ovale in paradoxical embolism, especially in the presence of pulmonary hypertension.

We thank Dr Antonio Giomi and Dr Maurizio Chiti for their help and advice in reviewing this case.

1 Sacco RL, Homma S, Di Tullio MR. Patent foramen ovale: a new risk factor for ischemic stroke. Heart Dis Stroke 1993;3:235-42.

2 Lechat P, Mas JL, Lascault G, Loron P, Theard M, Klimczac M, et al. Prevalence of patent foramen ovale in patients with stroke. N Engl F Med 1988;318:1148-52.

3 de Belder MA, Tourikis L, Leech G, Camm AJ. Risk of patent foramen ovale for thromboembolic events in al age groups. Am $\mathcal{F}$ Cardiol 1992;69:1316-20.

4 Prakash A, Chambers J, Holt P. Near miss paradoxical embolism. Br Heart $\mathcal{F}$ 1994;72:293.

5 Meister SG, Grossman W, Dexter L, Dalen JE Paradoxical embolism: diagnosis during life. $A m \mathcal{F} \mathrm{Med}$ 1972;53:292-8.

6 Dodson TF. Recognition and treatment of deep vein thrombosis. Heart Dis Stroke 1993;3:231-4. 